\title{
Energy Consumption and Carbon Dioxide Emissions of Residential Buildings in Lahore, Pakistan
}

\author{
Gul Zareen Ghafoor*, Faiza Sharif, Amin U Khan, Muhammad Umar Hayyat, \\ Muhammad Farhan, Laila Shahzad
}

Sustainable Development Study Center, Government College University, Lahore, Pakistan

\author{
Received: 26 February 2019 \\ Accepted: 12 May 2019
}

\begin{abstract}
In Pakistan, an increase in the urban population in recent decades has led to rising demand for energy and so has consequently increased carbon dioxide $\left(\mathrm{CO}_{2}\right)$ emissions. In this study, a questionnaire-based survey was conducted on a sample of 300 residential buildings in Lahore, and their $\mathrm{CO}_{2} \mathrm{e}$ emissions from electricity and natural gas consumption were calculated using IPCC methodology. The results show that both electricity and natural gas consumption released 7.65 $\mathrm{MMtCO}_{2} \mathrm{e}$ during the one-year study period. It was found that income class $(p<0.001)$, house area $(p<0.001)$, the size (tons) of AC $(p<0.001)$, number of kitchens $(p<0.01)$, building type $(p<0.001)$ and season $(p<0.001)$ had a significantly positive relationship with energy consumption and $\mathrm{CO}_{2} \mathrm{e}$ emissions. Conversely, roof insulation $(p<0.01)$ had a significantly negative relationship with energy consumption and $\mathrm{CO}_{2} \mathrm{e}$ emissions. The study emphasizes the need of policy formulation to improve thermal characteristics of existing buildings and implementation of building energy codes for new housing construction. It is also recommended to raise awareness among dwellers for the adoption of energy conservation measures to reduce $\mathrm{CO}_{2} \mathrm{e}$ emissions.
\end{abstract}

Keywords: $\mathrm{CO}_{2} \mathrm{e}$ emissions, electricity, natural gas, roof insulation, building type, residential buildings

\section{Introduction}

The Earth's climate is warming with a gradual rise in temperature due to the buildup of greenhouse gases (GHGs). The concentration of $\mathrm{CO}_{2}$ has risen from $278 \mathrm{ppm}$ (pre-industrial era) to $402.8 \mathrm{ppm}$ in 2015 and has caused a $1.4^{\circ} \mathrm{C}$ rise in average global temperature [1]. With this warming trend, the incidences of natural disasters have increased over the past four decades

*e-mail: zareen.sdsc@gmail.com and 2016 recorded the $3^{\text {rd }}$ consecutive warmest year, with a global average temperature rise of $0.90^{\circ} \mathrm{C}$ above the $20^{\text {th }}$ century average temperature [2]. A number of international treaties and conventions have been signed and ratified by many governments to avoid the devastating potential impacts of climate change by limiting global warming to $2^{\circ} \mathrm{C}$ as committed to in the Paris Agreement and subsequent commitments made in the Conference of Parties each year [1].

A significant amount of GHGs are being added by anthropogenic activities, including buildings, agriculture, solid waste disposal, industry, transport and 
energy sectors [1]. Being home to 207 million people, the residential buildings of Pakistan are consuming electricity (49\% of the total produced) and natural gas at an increasing rate with an estimated $15.7 \mathrm{MtCO}_{2}$ emissions (83 $\mathrm{kgCO}_{2}$ /capita) in 2017 [3, 4]. These emissions have led to a rise of $0.6-1^{\circ} \mathrm{C}$ in the average temperature of Pakistan since the early 1900s [5], resulting in increased precipitation in Northern areas, droughts (1999-2000), cyclone Phet (2010), floods (20102014), and heat waves in Karachi and other areas of Pakistan [6], which is prone to natural disasters and is listed at $25^{\text {th }}$ place in GHG-emitting countries and $10^{\text {th }}$ in the climate risk index (2015) of the top 10 most affected countries [7].

To house the burgeoning urban population of Pakistan, both high-density multistoried and low-density open localities (either single or double storey) can be seen in its metropolitan cities accommodating residents from different income groups. Most of the urban buildings either share one or two common walls with the adjacent building and use roof or wall insulation less commonly, which puts pressure on energy consumption during extremes of weather to achieve thermal comfort.

In residential buildings, energy consumption from space and water heating/cooling, lighting and other household demands are potent sources of $\mathrm{CO}_{2}$ emissions and have been found to be significantly related to household income. The insulation of the building envelope (walls and roof) and painted exterior (lighter reflective colors) play important roles in lowering residential energy demand by maintaining an indoor thermal balance $[8,9]$. Residential energy demand is also related to building design, floor area, the impact of local shadowing, household size and the number and quality of appliances used in a house [10]. The use of energy efficient heating and cooling technologies and changing building design have a potential to reduce GHG emissions up to $2 \mathrm{GtCO}_{2}$ by 2050 [11]. For a country like Pakistan, this target can be achieved by provision of solar technology at household level and by the use of thermal insulation, natural lighting, ventilation and energy efficient appliances as the recommendations set in National Climate Change Policy (2012) and Building Energy Code-Energy Provisions 2011 of Pakistan [12]. To achieve energy efficiency, proper policy formulation and implementation is required, which will also curtail GHG emissions. In Pakistan, very little work has been done on the quantification of carbon footprint from residential buildings, and most of the work has been done in the transport, industrial and energy sectors [13].

This paper is focused on the estimation of carbon emissions from operational energy consumption (electricity and natural gas) in residential buildings of the city district of Lahore, Pakistan. The objectives of this research were to: (1) find the carbon dioxide equivalent emissions $\left(\mathrm{CO}_{2} \mathrm{e}\right)$ from residential energy consumption during the operational phase, and (2) determine the relationship between factors affecting energy consumption and consequent GHG emissions.
It was hypothesized that income, the area of the house, building type, roof insulation, use of energy-intensive appliances, and seasonal variations can affect residential energy consumption and $\mathrm{CO}_{2} \mathrm{e}$ emissions.

\section{Materials and Methods}

\section{Study Area}

The study was conducted on the residential sector of Lahore $\left(31.5204^{\circ} \mathrm{N}, 74.3587^{\circ} \mathrm{E}\right)$. It has a semiarid climate with mean annual rainfall $(583 \mathrm{~mm})$ and temperatures reaching above $40^{\circ} \mathrm{C}$ in summer and near freezing point in winter with dense fog. The area receives insolation of $5.4 \mathrm{KWh} / \mathrm{m}^{2} /$ day. The burgeoning urban population of the study area makes it the second largest populated urban center of the country. In 2014, the total population of Lahore was 9.75 million, with a total buildup area of $1772.53 \mathrm{~km}^{2}$. The city is divided into nine administrative towns, i.e., Ravi, Allama Iqbal, Wagha, Shalimar, Data Ganj Baksh, Nishtar, Gulberg, Aziz Bhatti, and Samanabad and one cantonment area housing people from different income classes (Fig. 1). In these towns the single to multistoried houses are constructed with cement and bricks and mostly had lighter colored exteriors in order to reflect solar rays - especially in the long summer season. There were 731,000 household units in the city at the time of the survey provided with electricity and natural gas (NG) by two utility companies: Lahore Electric Supply Company (LESCO) and Sui Northern Gas Pipelines Ltd. (SNGPL) $[14,15]$.

\section{Study Design}

A questionnaire-based descriptive cross-sectional study was conducted by taking a random sample of 300 households derived using equation 1 [16] and ensuring representation of all socioeconomic classes from the study area. In equation $1, \mathrm{n}=$ sample size, $\mathrm{Z}=$ normal variate or confidence level (95\%), $\mathrm{h}=$ accepted error margin (5\%), and $\mathrm{P}$ and $\mathrm{Q}$ are the probability of success and failure taken $70 \%$ and $30 \%$, respectively:

$$
\mathrm{n}=(\mathrm{Z} / \mathrm{h})^{2} \mathrm{xPQ}
$$

This sample size was designed considering the total number of Lahore households, and values of $\mathrm{P}$ and $\mathrm{Q}$ were set based on responses of the pilot test (considering the study hypotheses) conducted before the main survey. For the main survey, representative areas of the city based on low-, middle- and high-income residential developments in the city were targeted and a random face-to-face survey was conducted with the household head ensuring representation from all nine towns and one cantonment area of the city.

Data on residential (operational) electricity and natural gas consumption was collected from the utility 


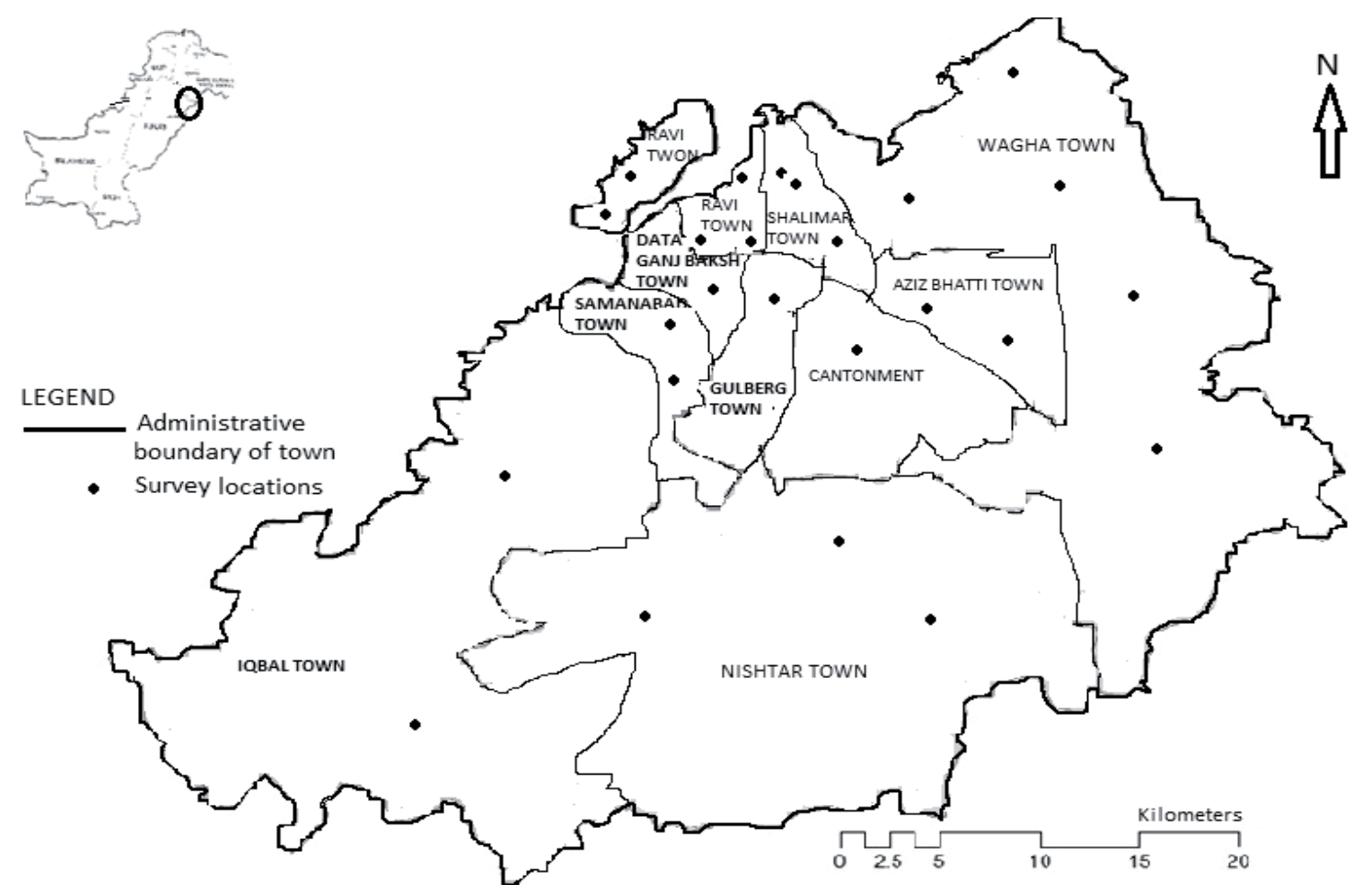

Fig. 1. Map of city district Lahore showing survey locations.

records provided by the respondents and where utility records were not available, the incomplete information was not considered for data analysis. In this manner, households were targeted for the survey more than the sample size designed, and only 300 responses with complete information were processed.

\section{Research Instrument and Household Survey}

A questionnaire of three sections concerned with demographics, building design, and the energy profile of the house was used for data collection. The demographic section was designed to acquire information about education, income class, household size, elderly family members ( $>60$ years of age) and family occupancy patterns. Respondents were asked about the design of their house such as building type (attached/detached), house area, number of rooms and kitchens, roof insulation, any tree/building casting a significant shadow on the building and paint shade of the exterior. Respondents were also asked about their major energy uses such as space and water heating and cooling systems, lighting type and energy backup systems. Energy consumption from personal/private transport and electricity generation through backup generators was not included in the study as invoices for fuel consumption were not available.

A pilot study was carried out on a small sample of households, and the instrument was modified wherever required based on responses to the pilot test. Later the survey was conducted and a sample of 300 households was taken with one year record of their electricity and natural gas consumption to determine the factors affecting energy consumption and $\mathrm{CO}_{2} \mathrm{e}$ emissions in the surveyed area.

\section{Estimation of Carbon Emissions}

Electricity and gas bills of one year were collected from surveyed households. Carbon emissions (million metric tons of $\mathrm{CO}_{2}$ e) for summer (March-October) and winter (November-February) seasons were calculated using the tier 1 approach of the Intergovernmental Panel on Climate Change as country-specific emission factors (EF) were not available [17] by applying Eqs 2-5 [17, 18]:

$$
\text { Emissions }_{\mathrm{GHG} \text {, fuel }}=\mathrm{FC}_{\text {fuel }} \times \mathrm{EF}_{\mathrm{GHG}} \text {, fuel }
$$

...where Emission ${ }_{\mathrm{GHG}}$, fuel $=$ GHG emissions from a certain type of fuel (electricity or natural gas in $\mathrm{kg}$ or metric ton), $\mathrm{FC}_{\text {fuel }}=$ amount of fuel combusted (TJ or $\mathrm{kWh}$ ), and $\mathrm{EF}{ }_{\mathrm{GHG}}$, fuel $=$ default emission factor for a certain GHG by fuel type ( $\mathrm{kg} \mathrm{GHG/TJ).}$

To calculate individual emissions from electricity and natural gas, Eq. 2 was modified:

$$
\begin{aligned}
\text { Electricity }_{\text {emissions }} & =\mathrm{FC}_{\text {electricity }} \times \mathrm{EF} \text { electricity } \\
\text { Natural Gas }_{\text {emissions }} & =\mathrm{FC}_{\text {natural gas }} \times \mathrm{EF}_{\text {natural gas }}
\end{aligned}
$$

When natural gas $(\mathrm{NG})$ is combusted it releases $\mathrm{CO}_{2}, \mathrm{CH}_{4}$ and $\mathrm{N}_{2} \mathrm{O}$. So it required quantification of all three gases, and total $\mathrm{CO}_{2}$ emissions were calculated as 
$\mathrm{CO}_{2}$ e by applying global warming potential (GWP) for each of the GHGs emitted during fuel consumption. For this, Eq. 4 was modified as [18]:

$$
\begin{aligned}
& \text { Natural Gas }{ }_{\text {emissions }}=\sum\left(\mathrm{FC}_{\text {natural gas }} \times \mathrm{EF}_{\mathrm{CO}_{2}}\right. \\
& \left.\times \mathrm{GWP}_{\mathrm{CO}_{2}}\right)+\left(\mathrm{FC}_{\text {natural gas }} \times \mathrm{EF}_{\mathrm{CH}_{4}} \times \mathrm{GWP}_{\mathrm{CH}_{4}}\right) \\
& +\left(\mathrm{FC}_{\text {natural gas }} \times \mathrm{EF} \mathrm{N}_{2} \mathrm{O} \times \mathrm{GWP}_{\mathrm{N}_{2} \mathrm{O}}\right)
\end{aligned}
$$

The country-specific grid electricity EF for Pakistan $\left(0.62163 \mathrm{KgCO}_{2} \mathrm{e} / \mathrm{kWh}\right)$ was adopted from [19], default EF for natural gas from IPCC tier 1 approach [17] and global warming potentials (GWP) from [18].

\section{Statistical Analysis}

Microsoft Office Excel (Version 2010) and Statistical Package for Social Sciences (SPSS) Version 21.0 were used to analyze survey data. Descriptive statistics were used to find frequencies and percentages of items inquired in the survey. One-way analysis of variance (ANOVA) was applied to study the effect of income and house area on energy consumption. Multiple comparisons were made using Tukey HSD. Multiple regression model was constructed to find the relationship between energy consumption and house area, number of kitchens, roof insulation and size of ACs. Univariate ANOVA was applied to determine the effects of building type, season and their interaction with energy consumption.

Average household emissions obtained from the current study were extrapolated to find $\mathrm{CO}_{2}$ e emissions from all the 731,000 households of Lahore as reported [15]. The extrapolated emissions were used to calculate potential rise in temperature by converting $\mathrm{CO}_{2} \mathrm{e}$ emissions into equal units of ppm and temperature [20].

\section{Results}

\section{Household Energy Use}

Results of the demographic profile, building characteristics and the residential energy use of the respondents are presented in Table 1. Education level of the respondents shows that $39 \%$ had a graduation degree, post-graduates (36\%) and $25 \%$ had matriculation (10 years of school education) or intermediate certifications (12 years of education). About $74.3 \%$ of the surveyed population had household size of $5-10$ persons and belonged to low (45.7\%), middle (35\%) and upper (19.3\%) income classes. The occupancy pattern showed high energy consumption from evening till early morning (74\%). Most of the houses (61\%) had elderly family members due to living in combined family systems.

Among the surveyed houses, $66 \%$ were living in houses with a floor area of $126.5 \mathrm{~m}^{2}$ to $252.9 \mathrm{~m}^{2}$ and only $9 \%$ were living in houses of $505.9 \mathrm{~m}^{2}$ or more. Of these,

\begin{tabular}{|c|c|}
\hline Variable & $\mathrm{N}(\%)$ \\
\hline \multicolumn{2}{|c|}{ Demographic profile } \\
\hline \multicolumn{2}{|c|}{ Education } \\
\hline Matriculation & $32(10.7)$ \\
\hline Intermediate & $43(14.3)$ \\
\hline Graduation & $117(39)$ \\
\hline Post graduate & $108(36)$ \\
\hline \multicolumn{2}{|c|}{ Household size (Persons) } \\
\hline$<5$ & $54(18)$ \\
\hline $5-10$ & $223(74.3)$ \\
\hline$>10$ & $23(7.7)$ \\
\hline \multicolumn{2}{|c|}{ Respondent's income group (PKR*/month) } \\
\hline Low $(<15,000-45,000)$ & $137(45.7)$ \\
\hline Middle $(45,001-75,000)$ & $105(35)$ \\
\hline Upper $(>75,000)$ & $58(19.3)$ \\
\hline \multicolumn{2}{|c|}{ Occupancy pattern } \\
\hline Daytime & $51(17)$ \\
\hline Evening & $28(9.3)$ \\
\hline Evening till early morning & $221(74)$ \\
\hline \multicolumn{2}{|c|}{ Elderly family member (age $\geq 60$ years) } \\
\hline Yes & $183(61)$ \\
\hline No & $118(39)$ \\
\hline \multicolumn{2}{|c|}{ Building characteristics } \\
\hline \multicolumn{2}{|c|}{ Type of building } \\
\hline Attached building & $274(91.3)$ \\
\hline Detached building & $26(8.5)$ \\
\hline \multicolumn{2}{|c|}{ House Area $\left(\mathrm{m}^{2}\right)$} \\
\hline$<126.5$ & $48(16)$ \\
\hline $126.5-252.9$ & $197(65.7)$ \\
\hline $252.9-404.7$ & $28(9.3)$ \\
\hline $404.7-505.9$ & $19(6.3)$ \\
\hline$>505.8$ & $8(2.7)$ \\
\hline \multicolumn{2}{|c|}{ Number of rooms } \\
\hline Less than 3 rooms & $34(11.3)$ \\
\hline 3-6 rooms & $155(51.7)$ \\
\hline More than 6 rooms & $111(37)$ \\
\hline \multicolumn{2}{|c|}{ Building's exterior paint shade } \\
\hline Light shade & $251(83.6)$ \\
\hline Dark shade & $49(16.4)$ \\
\hline \multicolumn{2}{|c|}{ Number of kitchens } \\
\hline Only one kitchen & $159(53)$ \\
\hline Two kitchens & $114(38)$ \\
\hline More than two kitchens & $27(9)$ \\
\hline
\end{tabular}

Table 1. Respondents' demographic profiles and building characteristics affecting household energy use. 
Table 1. Continued.

\begin{tabular}{|c|c|}
\hline Variable & $\mathbf{N}(\%)$ \\
\hline \multicolumn{2}{|c|}{ Insulation material } \\
\hline Polystyrene & $48(16)$ \\
\hline Thermo-pore & $39(13)$ \\
\hline No roof insulation & $213(71)$ \\
\hline \multicolumn{2}{|c|}{ Energy use } \\
\hline \multicolumn{2}{|c|}{ Space heater } \\
\hline Electrical & $45(15)$ \\
\hline Natural gas powered & $170(56.6)$ \\
\hline Both & $19(6.3)$ \\
\hline Do not have heater & $66(22)$ \\
\hline \multicolumn{2}{|c|}{ Separate heaters for each room } \\
\hline Yes & $65(21.6)$ \\
\hline No & $169(56.3)$ \\
\hline Do not have heater & $66(22)$ \\
\hline \multicolumn{2}{|c|}{ Fuel source of geyser } \\
\hline Electrical & $24(8)$ \\
\hline Natural gas powered & $189(63)$ \\
\hline Solar geyser & $3(1)$ \\
\hline Do not have geyser & $84(28)$ \\
\hline \multicolumn{2}{|c|}{ Number of geysers } \\
\hline Only one & $186(62)$ \\
\hline Two & $27(9)$ \\
\hline More than two & $3(1)$ \\
\hline Don't have geyser & $84(28)$ \\
\hline \multicolumn{2}{|c|}{ Conical baffle installed in geyser } \\
\hline Yes & $68(22.6)$ \\
\hline No & $111(37)$ \\
\hline Do not know & $10(3.3)$ \\
\hline Do not have geyser & $84(28)$ \\
\hline \multicolumn{2}{|c|}{ Instant geysers installed } \\
\hline Yes & $72(24)$ \\
\hline No & $228(76)$ \\
\hline
\end{tabular}

$91.3 \%$ of houses were attached from either one or two sides and only $8.5 \%$ were detached (free-standing) from adjacent house units, all with varying numbers of floors. Other variables such as the number of kitchens showed that $53 \%$ had one kitchen while $38 \%$ had two and $9 \%$ had more than two kitchens. Most of the houses (51.7\%) had 3-6 rooms. Both of these variables are determinants of energy demand for cooking, cooling and heating purposes. About $83.6 \%$ of house exteriors were painted with light color tones to lower the internal temperature of the building due to reflectance characteristics. In the current study, $77 \%$ of the respondents reported no tree causing significant shadow on their house, which could

\begin{tabular}{|c|c|}
\hline \multicolumn{2}{|c|}{ Electricity backup system } \\
\hline UPS & $167(55.6)$ \\
\hline Generator & $17(5.6)$ \\
\hline Solar UPS & $11(3.6)$ \\
\hline No backup & $105(35)$ \\
\hline \multicolumn{2}{|c|}{ Number of ACs } \\
\hline Only one & $112(37.3)$ \\
\hline Two & $68(22.6)$ \\
\hline More than two & $58(19.3)$ \\
\hline Do not have AC & $62(20.7)$ \\
\hline \multicolumn{2}{|c|}{ Size of $\mathrm{AC}$} \\
\hline 1 ton & $60(20)$ \\
\hline 1.5 ton & $143(47.6)$ \\
\hline 2 ton & $35(11.6)$ \\
\hline Do not have AC & $62(20.7)$ \\
\hline \multicolumn{2}{|c|}{ Hours of AC usage (Daily) } \\
\hline$<6$ hours & $34(11.3)$ \\
\hline $6-10$ hours & $126(42)$ \\
\hline$>10$ hours & $78(26)$ \\
\hline Do not have AC & $62(20.7)$ \\
\hline \multicolumn{2}{|c|}{ Type of lighting in house } \\
\hline FTL & $35(11.7)$ \\
\hline CFLs & $148(49.3)$ \\
\hline Incandescent bulb & $3(1)$ \\
\hline FTL and LED lights & $114(38)$ \\
\hline \multicolumn{2}{|c|}{ Type of gas backup system } \\
\hline Gas compressor & $29(9.6)$ \\
\hline Gas cylinder & $67(22)$ \\
\hline Both & $1(0.3)$ \\
\hline Any other & $5(1.6)$ \\
\hline No backup & $198(66)$ \\
\hline
\end{tabular}

$\mathrm{N}=$ Frequency, $\%=$ Percentage, $*(104.8 \mathrm{PKR}=1 \mathrm{USD}$ as per exchange rate of year 2017)

affect energy demand. The majority of the houses (71\%) did not have any roof insulation, while only $16 \%$ of houses had polystyrene and thermo-pore $(13 \%)$ insulated roofs.

A complete analysis of residential electricity and natural gas (NG) consumption was conducted. The majority of the houses had employed space heating $(15 \%$ electrical space heaters, 56.6\% NG, 6.3\% both) and cooling systems (79\% with air conditioners installed). There was high dependence on NG (63\%) for water heating purposes and $71 \%$ of the houses had one or more geysers installed (either electric, natural gas or solar). The conical baffle installation in the geysers 
was reported by $22.6 \%$ and the instant geyser (either electric or gas powered) installation by $24 \%$ of the respondents. Only $22 \%$ of respondents were relying on gas cylinders as backup in the case of gas load shedding for cooking and water heating purposes. The majority of the houses $(55.6 \%)$ were using electricity to charge UPS (uninterruptible power supply) and 5\% were using a generator (to produce electricity) as back-up in case of power outage, while the use of solar UPS was very rare $(3.6 \%)$. There was high utilization of electricity in the current study for space cooling because the majority of the respondents had either one (37.3\%), two (22.7\%) or more than two $(19.3 \%)$ air conditioners (AC) installed in their homes. Sizes of ACs ranged from 1 ton (20\%), 1.5 tons $(47.6 \%)$, and 2 tons $(11.6 \%)$, with $62 \%$ running for 6-10 hours a day. For lighting, 49.3\% of the houses used compact fluorescent lamps (CFLs), while 11.7\% used fluorescent tube lights (FTLs), halogen bulbs (1\%), and both light-emitting diodes (LEDs) and FTLs (38\%).

\section{Relationship between Energy Consumption and Other Variables}

On average, $2890 \pm 86.3 \mathrm{KWh}$ of electricity and $11.84 \pm 0.33 \mathrm{Hm}^{3}\left(1 \mathrm{Hm}^{3}=1000000 \mathrm{~m}^{3}=35311 \mathrm{BTU}\right)$ of NG was consumed in the surveyed houses. It can be seen from Table 2 that both electricity and gas consumption were significantly higher in the houses of areas greater than $404.7 \mathrm{~m}^{2}(p<0.001)$. A similar kind of relationship was observed between income and electricity consumption, with significantly higher $(p<0.001)$ consumption by middle and upper income classes. No statistically significant relationship was observed between income and NG consumption because most of the residential stock of the city faces a gas shortage or load shedding when its demand is high in winter season.

Multiple regression analysis was conducted to evaluate the determinants of annual energy consumption by constructing a model representing the variables of electricity and NG consumption (Table 3). In the analysis, $R^{2}$ explained $13 \%$ and $12 \%$ variations in electricity and gas consumption, respectively, in influence of explanatory variables of the model. According to adjusted $R^{2}$ and $F$ statistics, the model was a good fit at $p=0.000$ in case of both energy sources. The term constant explains the affects of variables, which were extraneous to the model and which significantly affected annual energy consumption $(p<0.01$ and $p<0.001$ respectively). Area of the house $(p<0.001)$ and number of kitchens $(p<0.01)$ had a significant positive relationship with electricity and gas consumption, while application of roof insulating material $(p<0.01)$ had a significant negative relationship with gas consumption.

\section{Carbon Dioxide Emissions $\left(\mathrm{CO}_{2} \mathrm{e}\right)$}

It was found that the surveyed houses in Lahore released $7.65 \mathrm{MMtCO}_{2} \mathrm{e} /$ year (average $25.50 \pm 0.72 \mathrm{ktCO}_{2} \mathrm{e} /$ house) from both electricity and gas consumption. On average, electricity consumption was higher in the summer months (March-October) with the maximum in August $(358.32 \pm 14.12 \mathrm{KWh})$, and is

Table 2. ANOVA of electricity and gas consumption with house area and income.

\begin{tabular}{|c|c|c|}
\hline \multirow{2}{*}{ Variables } & Electricity consumption (KWh) & Gas consumption $\left(\mathrm{Hm}^{3}\right)$ \\
\hline & Mean \pm S.E & Mean \pm S.E \\
\hline \multicolumn{3}{|c|}{ House area $\left(\mathrm{m}^{2}\right)$} \\
\hline$<126.5$ & $2600 \pm 244^{c}$ & $9.49 \pm 0.733^{\mathrm{c}}$ \\
\hline $126.5-252.9$ & $2732 \pm 942^{\mathrm{c}}$ & $11.64 \pm 0.381^{\mathrm{c}}$ \\
\hline $252.9-404.7$ & $3039 \pm 284^{\text {bc }}$ & $12.14 \pm 0.884^{\mathrm{bc}}$ \\
\hline $404.7-505.9$ & $4116 \pm 339^{\mathrm{ab}}$ & $17.45 \pm 1.751^{\mathrm{a}}$ \\
\hline$>505.8$ & $5088 \pm 521^{\mathrm{a}}$ & $16.61 \pm 2.920^{\mathrm{ab}}$ \\
\hline Summary Statistics & $\mathrm{df}=4, F=9.569, p=0.000$ & $\mathrm{df}=4, F=8.512, p=0.000$ \\
\hline \multicolumn{3}{|c|}{ Income classes } \\
\hline Low & $2486 \pm 115^{b}$ & $11.41 \pm 0.46$ \\
\hline Middle & $3121 \pm 143^{\text {a }}$ & $12.10 \pm 0.55$ \\
\hline Upper & $3425 \pm 213^{a}$ & $12.26 \pm 0.94$ \\
\hline \multirow{2}{*}{ Summary Statistics } & $\mathrm{df}=2, F=10.612$ & $\mathrm{df}=2, F=0.695$ \\
\hline & $p=0.000$ & $p=0.500$ \\
\hline
\end{tabular}

$S . E=$ Standard Error

Means followed by different letters in a column for a particular variable differ significantly at $p<0.001$ (Tukey HSD). 
Table 3. Model - estimates of the determinants of annual electricity and natural gas consumption using multiple regression analysis.

\begin{tabular}{|c|c|c|c|c|}
\hline \multicolumn{7}{|c|}{ Model } & B & S.E & T & Sig. \\
\hline \multicolumn{7}{|c|}{ Electricity consumption } \\
\hline (Constant) & 0.380 & 0.173 & 1.308 & 0.001 \\
\hline House area & 0.255 & 0.052 & 6.382 & 0.000 \\
\hline Size of AC & 0.168 & 0.034 & 3.352 & 0.001 \\
\hline Summary Statistics & $R^{2}=0.13$, Adjusted $R^{2}=0.11$, S.E. of estimate $=2.12, F$-Statistics $=10.98, p=0.000$ \\
\hline \multicolumn{7}{|c|}{ NG consumption } \\
\hline (Constant) & 1.739 & 0.218 & 7.985 & 0.000 \\
\hline House area & 0.201 & 0.044 & 4.546 & 0.000 \\
\hline Number of kitchens & 0.177 & 0.058 & 3.044 & 0.003 \\
\hline Roof insulation & -0.163 & 0.049 & -3.314 & 0.001 \\
\hline Summary Statistics & $R^{2}=0.12$, Adjusted $R^{2}=0.11$, S.E. of estimate $=3.41, F$-Statistics $=10.80, p=0.000$ \\
\hline
\end{tabular}

$B=$ co-efficient, $S . E .=$ Standard error

lower in the winter season (November-February) with a minimum in February (139.66 $\pm 5.08 \mathrm{KWh}$ ) (Fig. 2). An opposite trend can be observed in NG consumption, where it was minimum in October $\left(0.58 \pm 0.01 \mathrm{Hm}^{3}\right)$ and maximum in February $\left(1.52 \pm 0.06 \mathrm{Hm}^{3}\right)$. Higher monthly gas consumption was observed during the winter season. There was more dependence on NG for space and water heating during the winter season (4.50 $\left.\mathrm{Hm}^{3}\right)$, but when taken collectively for the long summer season (March-October), gas consumption was found to be higher $\left(7.34 \mathrm{Hm}^{3}\right)$ because of its high demand as a generator fuel during extended power outage hours in this season. During the study period, the sampled households consumed a total of $867,127 \mathrm{KWh}$ of electricity and $3,553.5 \mathrm{Hm}^{3}$ of natural gas.

A similar trend in electricity and gas emissions can be seen in Fig. 3, which shows that electricity emissions peaked in August $\left(66.82 \mathrm{tCO}_{2} \mathrm{e}\right)$ and were at a minimum in February $\left(26.04 \mathrm{tCO}_{2} \mathrm{e}\right)$. GHG emissions from gas consumption were highest in February (986310 $\left.\mathrm{tCO}_{2} \mathrm{e}\right)$ and lowest in October $\left(375108 \mathrm{tCO}_{2} \mathrm{e}\right)$. With the onset of winter, GHG emissions from gas consumption started increasing gradually from November to February, with a minimum of $439996 \mathrm{tCO}_{2} \mathrm{e}$ in November.

\section{Building Type and $\mathrm{CO}_{2}$ e Emissions}

Results of Univariate ANOVA revealed that both electricity and gas consumption were significantly affected by building type $(p<0.001)$ and season $(p<0.001)$, respectively (Table 4). However, the interaction of the two variables (building type $\times$ season) was significant for electricity consumption only $(p<0.05)$. Both electricity and gas consumption were higher in detached buildings than attached buildings (Table 5). Also, energy consumption was significantly associated with season, as (on average) both electricity and gas consumption were high in summer due to the

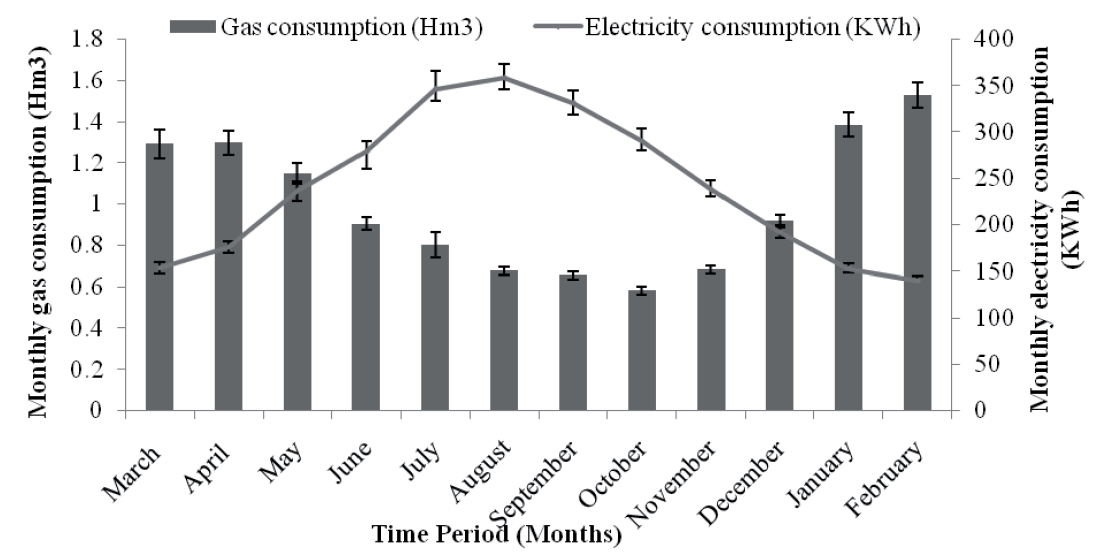

Fig. 2. Average monthly electricity and gas consumption in surveyed residential buildings. 


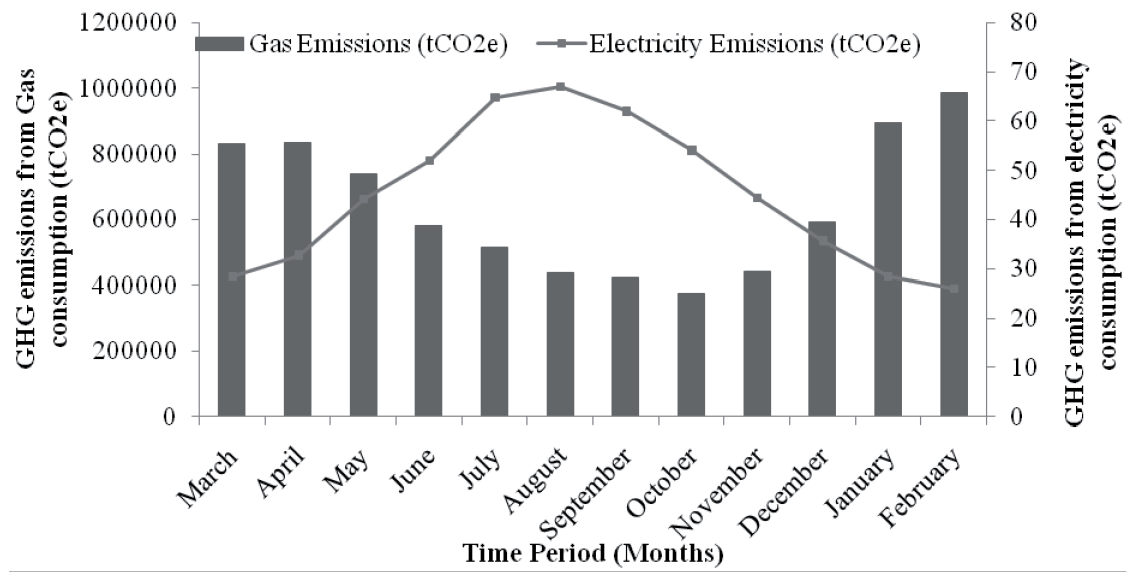

Fig. 3. Total monthly GHG emissions from electricity and gas consumption in one year.

use of $\mathrm{AC}$ and energy backup systems as mentioned above. This trend in energy consumption can be related to $\mathrm{CO}_{2} \mathrm{e}$ emissions in both types of buildings. On average, a detached building had higher $\mathrm{CO}_{2} \mathrm{e}$ emissions (2.46E-9 $\pm 2.29 \mathrm{E}-10 \quad \mathrm{tCO}_{2} \mathrm{e}$ from electricity and $32736 \pm 2426.4 \mathrm{tCO}_{2} \mathrm{e}$ from $\left.\mathrm{NG}\right)$ as compared to the attached buildings $\left(1.76 \mathrm{E}-9 \pm 5.38 \mathrm{E}-11 \mathrm{tCO}_{2} \mathrm{e}\right.$ from electricity and $25090 \pm 761.2 \mathrm{tCO}_{2} \mathrm{e}$ from NG).

On the basis of average annual household $\mathrm{CO}_{2} \mathrm{e}$ emissions (0.0255 $\quad \mathrm{MMtCO}_{2} \mathrm{e} /$ household $), \quad$ data was extrapolated for 731,000 Lahore households (Government of Punjab, 2013), and carbon emissions of $18.64 \mathrm{GtCO}_{2} \mathrm{e}(8.76 \mathrm{ppm})$ were estimated from the city's residential building stock. The estimated emissions have a potential to raise atmospheric temperature by $0.07^{\circ} \mathrm{C}$ [20].

\section{Discussion}

Findings of this study revealed a strong association between income and energy consumption, which prompts dwellers to improve their standard of living. In the present study significantly higher electricity consumption was reported from middle and upper

Table 4. Univariate ANOVA of energy consumption with building type and season.

\begin{tabular}{|c|c|c|c|}
\hline Variables & Df & F & Sig. \\
\hline \multicolumn{4}{|c|}{ Electricity Consumption } \\
\hline Building type & 1 & 18.58 & 0.000 \\
\hline Season & 1 & 178.164 & 0.000 \\
\hline Building type $\times$ Season & 1 & 6.037 & 0.014 \\
\hline \multicolumn{4}{|c|}{ Gas Consumption } \\
\hline Building type & 1 & 13.410 & 0.000 \\
\hline Season & 1 & 38.097 & 0.000 \\
\hline Building type $\times$ Season & 1 & 0.189 & 0.664 \\
\hline
\end{tabular}

income classes. Kus et al. [21] has reported a similar relationship of electricity consumption with income $(p<0.001)$ in Turkey. Energy consumption is also related with time spent in the house. Santin et al. [22] found a significant relationship $(p<0.001)$ between occupancy pattern and domestic energy consumption as related to the operation of different appliances for variable times of day.

According to the survey results, energy consumption and $\mathrm{CO}_{2} \mathrm{e}$ emissions were significantly higher in detached buildings than in the attached houses in both seasons. On average, detached buildings were consuming $564 \mathrm{KWh} /$ year and $1.775 \mathrm{Hm}^{3} /$ year of electricity and gas in excess to attached houses. Yohanis et al. [23] reported a similar relationship between building type and $\mathrm{CO}_{2}$ emissions with changing weather patterns in the United Kingdom, where detached houses were consuming $1.27 \mathrm{KWh} / \mathrm{m}^{2} /$ month in excess to attached houses. Detached buildings for being exposed to weather extremes on all sides require more temperature regulation than an attached building, resulting in high energy utilization and GHG emissions.

It has been established through this and previous studies that an attached building or a building employed with wall and roof insulation can help in conserving energy and reducing GHG emissions. But current housing practices in Lahore, especially in most popular

Table 5. Relationships of energy consumption with building type and seasons.

\begin{tabular}{|c|c|c|c|}
\hline \multicolumn{2}{|c|}{ Variables } & $\begin{array}{c}\text { Electricity } \\
\text { consumption } \\
(\mathrm{KWh}) \\
\text { Mean } \pm \text { S.E. }\end{array}$ & $\begin{array}{c}\text { Gas } \\
\text { Consumption } \\
\left(\mathrm{Hm}^{3}\right) \\
\text { Mean } \pm \text { S.E. }\end{array}$ \\
\hline \multirow{2}{*}{$\begin{array}{c}\text { Building } \\
\text { type }\end{array}$} & Attached & $1416 \pm 48.11$ & $5.826 \pm 0.15$ \\
\cline { 2 - 4 } & Detached & $1980 \pm 205.73$ & $7.601 \pm 0.50$ \\
\hline \multirow{2}{*}{ Season } & Summer & $2200 \pm 70.16$ & $7.389 \pm 0.23$ \\
\cline { 2 - 4 } & Winter & $730.4 \pm 24.93$ & $4.571 \pm 0.15$ \\
\hline
\end{tabular}


housing schemes such as the Defence Housing Authority (DHA), requires the buildings to be constructed as detached from all sides (area $>505.9 \mathrm{~m}^{2}$ or higher) or with one common wall (area 252.9-505.9 $\mathrm{m}^{2}$ ), neglecting the effect of ambient temperature on the building's indoor temperature.

There was very little utilization of roof insulation in the study area. In Pakistan, most houses are built as simple concrete structures with little room for insulation, neglecting the need for energy conservation in hot weather and thus putting pressure on energy resources. Insulating materials such as polystyrene/thermopore, polyurethane and limestone-cement mix are most widely used globally, but there is little awareness on their use in Pakistan. Also, there is need to change construction practices in Pakistan as the houses constructed of baked clay blocks have little room to accommodate 16-20" of insulation in the ceiling and of 12" in the wall [12, 24].

The Building Energy Code of Pakistan (Energy Provisions 2011) [24] has made necessary amendments in building bylaws for high-end domestic and commercial users to save $25-30 \%$ of energy in new and existing construction, with the total connected load of $100 \mathrm{KW}$ or air-conditioned area of $900 \mathrm{~m}^{2}$, but these measures are not in practice at present. Efficient energy reduction can be achieved by improving the building envelope (wall and roof material), HVAC (heating, ventilation, air conditioning and cooling) and lighting. But unfortunately there are no energy standards for residential buildings that do not fall in the abovementioned category.

Painting the building exterior with lighter color tones or employing some shading mechanism (either trees or window glazing) can further help in reducing operational energy utilization. Bakhlah and Hassan [9] reported a reduction of $0.1-2.3^{\circ} \mathrm{C}$ in indoor air temperature with the application of white paint to the building envelopes. In this study both electricity and gas consumption were significantly higher in house areas greater than 404.7 $\mathrm{m}^{2}$, and is consistent with the findings of Kus et al. [21] as larger houses require more energy to set the kitchen or other rooms. There was a high use of ACs, electrical or gas space and water heaters and UPS in the study area putting increasing demand for electricity and gas in both seasons. However, in the majority of houses energy-efficient lights (CFLs and LEDs) were in use, showing the concern of respondents to lower electricity consumption and associated cost/bills as a result of media campaigns [25]. According to estimates, a CFL (9-13W) or LED (4-5W) consumes much less electricity to provide 450 lumens, as compared to an incandescent bulb (40W) to provide equivalent lumens. Keeping in consideration the benefits of LEDs and CFLs, if all of the surveyed houses are shifted to energy-efficient lights and other appliances, significant reduction in operational electricity consumption and $\mathrm{CO}_{2} \mathrm{e}$ emissions can be achieved. These measures along with environmental benefits can help in achieving monetary incentives in the form of reduced utility bills.
Residential GHG emissions can also be lowered by promoting solar energy at the domestic level. Pakistan lies in a solar belt receiving 4.45-5.83 $\mathrm{kWh} / \mathrm{m}^{2} /$ day of insolation, thus having generation capacity of 2.9 million MW of solar energy [26]. Considering this aspect, it was proposed in Pakistan Budget 2016-2017 to give relief on customs duty for the import of solar panels and local manufacturing of LED lights in order to promote renewable energy technologies.

Ramachandra et al. [27] reported 38,633.2 Gg and $22,783.08 \mathrm{Gg}$ (a share of $30.26 \%$ and $37.2 \%$ residential $\mathrm{CO}_{2} \mathrm{e}$ emissions, respectively) of emissions from all energy-consuming sectors of Delhi and Mumbai respectively, which are much lower than the extrapolated estimations $\left(18.64 \mathrm{GtCO}_{2} \mathrm{e}\right)$ of the current study. In another study, Bangalore, India is reported to release $1940.62 \mathrm{GgCO}_{2} /$ year from electricity consumption in the domestic sector [28], which is higher than the consumption found in the current study (1313 $\left.\mathrm{GgCO}_{2} \mathrm{e}\right)$. The difference in $\mathrm{CO}_{2} \mathrm{e}$ emissions among countries and at global scale arise due to the difference in use of EF and methodological approach (using country specific or default EF). Various datasets such as IPCC (1996 and 2006 guidelines), International Energy Agency (IEA) energy balances, Energy Information Administration (EIA) and UNFCCC are available reporting methodologies and data sources for calculating emissions for Annex-I and non Annex-I countries [3, 27, 29]. Owing to the vast datasets (EFs and methodologies) available, there exist uncertainties in emission estimates reported by individual countries and so cannot be compared. Even the emissions reported in the National GHG inventory, provided in Pak-INDC for Paris Agreement, are not to be considered precise and highly accurate.

On the basis of $\mathrm{CO}_{2} \mathrm{e}$ emission extrapolation, the current study estimated a rise of $0.07^{\circ} \mathrm{C}$ temperature, which seems negligible but this is only from electricity and gas consumption of the residential sector of Lahore and did not include other $\mathrm{CO}_{2}$ emission sources by residents like diesel/patrol used in the generators and the use of private transport. If the emissions are calculated for other energy-consuming sectors of the city or country, then the impact will be significantly higher. The estimated $\mathrm{CO}_{2} \mathrm{e}$ emissions cannot always lead to an estimated increase in temperature because a part of this is sequestered in the natural carbon cycle, but still the issue cannot be ignored considering the present national and global emission trends. So there is a need to calculate the carbon footprint of all energyconsuming sectors of the country to meet Pakistan's INDC commitments made during the Paris Agreement. Further reduction in energy utilization can be achieved by initiating a system of conducting energy audits of the buildings on a regular basis and by initiating residential energy efficiency programs, as are in practice in many countries [30]. This will lead to a win-win situation by saving money on utility bills, energy conservation and reduced carbon emissions. 


\section{Conclusion and Policy Implications}

This study concludes that monthly income, house floor area, roof insulation, building type and season had a significant effect on energy consumption and $\mathrm{CO}_{2} \mathrm{e}$ emissions. There was rare use of roof insulating materials in surveyed houses, which led to an increase in energy consumption and related emissions in both seasons. Findings of this study suggest that a periodic system of energy audits/monitoring energy consumption needs to be formulated to check gaps in achieving energy efficiency and to raise awareness among dwellers about the causes and consequences of global warming in order to lower their energy consumption to reduce carbon emissions. Also, policymakers should make an active policy to implement Pakistan Building Energy Code Energy Provisions 2011 (not in practice at present) in order to improve thermal performance of new and existing residential buildings (irrespective of the floor area and air conditioned space) - focusing on all aspects of building design (such as material composition and building orientation). This will help lower energy consumption in all best and possible ways. Keeping in consideration the international pressure on reducing GHG emissions, the Pakistani Government should invest in renewable energy projects, such as hydroelectricity, biogas and solar power. The government should promote solar power by giving relief on custom duty to import solar panels and related components (batteries, charge controller and inverters). This needs to be done in order to make it affordable for residential stock and other sectors in all cities of the country as has been done in Bahawalpur (Quaid-e-Azam Solar Park) in order to harvest solar energy, which will not only reduce GHG emissions but will also help lower pressure on the finite energy resources of the country.

\section{Acknowledgements}

This research is not part of any project and so did not receive any funding from the public, or commercial and non-profit organizations. The corresponding author is thankful to all the coauthors for providing their technical guidance to complete this work.

\section{Conflict of Interest}

There is no conflict of interest in this research.

\section{References}

1. IEA. Energy and Climate Change. World Energy Outlook Special Report. International Energy Agency, 75739 Paris Cadex 15, France. 2015.

2. HENDERSON R.M., REINERT S.A., DEKHTYAR P., MIGDAL A. Climate Change in 2018: Implications for Business. Harvard Business School. 2015.
3. IEA. $\mathrm{CO}_{2}$ emissions from fuel combustion, Highlights. International Energy Agency, 75739 Paris Cedex 15, France. 2017.

4. RASHID T., SAHIR M.H. Modeling and analysis of long term energy demand in residential sector of Pakistan. Tech. J. Uni. Eng. Tech. (UET) Taxila. Pak. 20 (3), 11, 2015.

5. PARRY M., CANZIANI O., PALUTIKOF J., Eds. Climate change 2007: impacts, adaptation and vulnerability (Vol. 4). Cambridge: Cambridge University Press. 2007.

6. GOVERNMENT OF PAKISTAN. Technical report on Karachi heat wave June 2015. Ministry of Climate Change Government of Pakistan. 2015.

7. GERMANWATCH. Global Climate risk Index: Who suffers most from extreme weather event? Weather related loss event in 2013 and 1994 to 2013. 2015.

8. AHMED K., ARIF S., KHAN A., MUSHTAQ M. Effect of Low Cost Roof Insulating Materials on Indoor Temperature of Buildings In Lahore. P. J. Sci. 65 (2), 2013.

9. BAKHLAH M.S., HASSAN A.S. The Effect of Roof Colour on Indoor House Temperature In Case of Hadhramout, Yemen. Am. Trans. Eng. Appl. Sci. 1 (4), 2229, 2012.

10. KAVOUSIAN A., RAJAGOPAL R., FISCHER M. Determinants of residential electricity consumption: Using smart meter data to examine the effect of climate, building characteristics, appliance stock, and occupants' behavior. Energy. 55, 184, 2013.

11. IEA. Technology roadmap: Energy efficient buildings: heating and cooling equipment. International Energy Agency, 75739 Paris Cadex 15, France. 2011.

12. KHALID A., RAZA S. Economic and environmental benefits of adopting energy efficiency methods for a typical house in Pakistan. In Proceeding of international conference on energy and sustainability. NED Karachi (Vol. 5). 2013.

13. MALIK W., SHAHID H., ZAFAR R., UDDIN Z., WAZIR Z., ANWAR Z., KHATTAK J.Z.K., ALI S.S. Role of Pakistan in global climate change through greenhouse gas emissions (GHGs). Res. J. Env. Earth. Sci. 4 (11), 996, 2012.

14. SAJJAD S.H., BATOOL R., QADRI S.T., SHIRAZI S.A., SHAKRULLAH K. The long-term variability in minimum and maximum temperature trends and heat island of Lahore city, Pakistan. Sci. Int. (Lahore), 27 (2), 1321, 2015.

15. GOVERNMENT OF PUNJAB. Punjab Development Statistics 2013. Bureau of Statistics Government of the Punjab Lahore. 2013

16. CASLEY D.J., KUMAR K. The collection, analysis and use of monitoring and evaluation data. The World Bank. 1988.

17. IPCC. 2006 guidelines for National greenhouse gas inventories: Volume 2 (Energy), In: Eggleston H. S., Buendia L., Miwa K., Ngara T., Tanabe K. (Eds). The National Greenhouse Gas Inventories Programme. IGES, Japan. 2006.

18. UNEP SBCI. Metric and Protocol for measuring and reporting the global warming potential (GWP) of buildings. UNEP Sustainable Buildings and Construction Initiative (SBCI). 2009.

19. DEFRA. Greenhouse gas conversion factors for company reporting 2012 guidelines. Department of Environment Food and Rural Affairs and Department of Energy and Climate Change. 2012.

20. WORLD CLIMATE REPORT. What you can't do about global warming. Available online: http://www. 
worldclimatereport.com/index.php/2009/04/30/what-youcant-do-about-global-warming/. (Accessed 06.06.16).

21. KUS M., AKAN P., KOKSAL M.A., GULLU G. Determining residential energy consumption-based $\mathrm{CO}_{2}$ emissions and examining the factors affecting the variation in Ankara, Turkey. In E3S Web of Conferences, 22, EDP Sciences. 2017.

22. SANTIN O.G., ITARD L., VISSCHER H. The effect of occupancy and building characteristics on energy use for space and water heating in Dutch residential stock. Energ. Buildings. 41 (11), 1223, 2009.

23. YOHANIS Y.G., MONDOL J.D., WRIGHT A., NORTON B. Real-life energy use in the UK: How occupancy and dwelling characteristics affect domestic electricity use. Energ. Buildings. 40 (6), 1053, 2008.

24. SOHAIL A., QURESHI M.D. Energy efficient buildings in Pakistan. Sci. Vision. 16 (17), 27, 2010-2011.

25. CHUN N., JIANG Y. Adoption of CFLs and Electrical Lighting Usage in Pakistan. 2012.
26. MIRZA I.A., KHALIL M.S. Renewable energy in Pakistan: opportunities and challenges. Sci. Vision. 16, 13, 2011.

27. RAMACHANDRA T.V., AITHAL B.H., SREEJITH K. GHG footprint of major cities in India. Renew. Sust. Energ. Rev. 44, 473, 2015.

28. BAJPAI V., KULKARNI G., HAN S.S., RAMACHANDRA T.V. Carbon emissions due to electricity consumption in the residential sector. Lake 2012: National Conference on Conservation and Management of Wetland Ecosystems. 2012.

29. PBL \& JRC. Trends in Global $\mathrm{CO}_{2}$ emissions 2014 ReportBackground Studies. PBL Netherlands Environmental Assessment Agency \& Joint Research Center. 2014.

30. BERGES M.E., GOLDMAN E., MATTHEWS H.S., SOIBELMAN L. Enhancing electricity audits in residential buildings with nonintrusive load monitoring. J. Ind. Ecol. 14 (5), 844, 2010. 
